\title{
Protein resistance efficacy of PEO-silane amphiphiles: Dependence on PEO-segment length and concentration
}

\author{
Marc A. Rufin, ${ }^{\dagger}$ Mikayla E. Barry, ${ }^{\dagger}$ Paige A. Adair, ${ }^{\dagger}$ Melissa L. Hawkins, ${ }^{\dagger}$ \\ Jeffery E. Raymond, ${ }^{\not}$ and Melissa A. Grunlan*, ${ }^{+}, \mathbb{H}$ \\ ${ }^{\dagger}$ Department of Biomedical Engineering, ${ }^{t}$ Department of Chemistry, \\ ${ }$ Department of Materials Science and Engineering \\ Texas A\&M University \\ *Email: mgrunlan@tamu.edu \\ Phone: 1-979-845-2406 \\ Fax: 1-979-845-4450 \\ 5030 Emerging Technologies Building \\ 3120 TAMU \\ College Station, TX 77843-3120
}

\begin{abstract}
In contrast to modification with conventional PEO-silanes (i.e. no siloxane tether), silicones with dramatically enhanced protein resistance have been previously achieved via bulkmodification with poly(ethylene oxide) (PEO)-silane amphiphiles $\alpha-(\mathrm{EtO})_{3} \mathrm{Si}\left(\mathrm{CH}_{2}\right)_{2}{ }^{-}$ oligodimethylsiloxane 13 -block $-\mathrm{PEO}_{n}-\mathrm{OCH}_{3}$ when $n=8$ and 16 but not when $n=3$. In this work, their efficacy was evaluated in terms of optimal PEO-segment length and minimum concentration required in silicone. For each PEO-silane amphiphile $(n=3,8$, and 16), five concentrations $(5,10,25,50$, and $100 \mu \mathrm{mol}$ per $1 \mathrm{~g}$ silicone) were evaluated. Efficacy was quantified in terms of the modified silicones' abilities to undergo rapid, water-driven surface restructuring to form hydrophilic surfaces as well as resistance to fibrinogen adsorption. Only $n$ $=8$ and 16 were effective, with a lower minimum concentration in silicone required for $n=8$ (10 $\mu$ mol per $1 \mathrm{~g}$ silicone $)$ versus $n=16(25 \mu \mathrm{mol}$ per $1 \mathrm{~g}$ silicone $)$.
\end{abstract}

Keywords: Poly(ethylene oxide), surface-modifying additive, surface restructuring, silicone, protein-resistant 


\section{Introduction}

Silicone is a widely used material for blood-contacting medical devices such as hemodialysis catheters, catheter balloons, and cardiac pacing leads [1, 2]. Silicone materials strike an excellent balance of durability, flexibility, and processability that makes them wellsuited for such applications. Unfortunately, due to their hydrophobic nature, silicones suffer from poor resistance to protein adsorption which causes subsequent thrombus formation [3]. This surface-induced thrombosis may lead to a variety of device complications including obstruction of blood flow [4], thromboemboli [5, 6], and infection [7, 8], all of which result in diminished device efficacy or failure, ultimately jeopardizing patient health. Antithrombotic drugs can reduce such complications $[9,10]$ but put the patient at risk for major bleeding events $[11,12]$. Therefore, silicone materials that are inherently resistant to protein adsorption and thrombosis, thereby reducing the need for antithrombotic drugs, would dramatically improve the efficacy and safety of blood-contacting medical devices.

Perhaps the most popular strategy to achieve protein resistance is the introduction of poly(ethylene oxide) [PEO or poly(ethylene glycol) (PEG)] to model substrates (e.g. gold and silicon) [13-17] as well as to various biomaterials [18-22] including silicone [23-27]. PEO inhibits protein adsorption by a number of mechanisms including steric repulsion [28, 29], blockage of underlying adsorption sites [30], and formation of a repulsive "hydration layer" [31]. Furthermore, in addition to its biocompatibility [32], PEO's excellent oxidative stability under biological conditions has been demonstrated [33]. Despite the promising performance of PEO coatings in vitro, their performance in vivo has been disappointing and inconsistent [34-36].

In order for PEO to effectively diminish protein adsorption, its surface concentration must be sufficiently high $[14,15,37,38]$. Thus, for the modification of silicones, it is critical that 
a PEO-enriched surface is formed at the aqueous (i.e. biological) interface where protein adsorption occurs. Due to the low surface energy [39] and high chain flexibility [40] of silicones, surface reorganization occurs depending on the environment (e.g. in air or underwater) [41]. For example, silicone can be plasma-treated to improve surface hydrophilicity, but unless maintained in water, it will undergo hydrophobic recovery [42]. Both bulk- and surface-modification strategies used to introduce PEO into silicone have been shown to similarly undergo hydrophobic recovery. These include silicones bulk-crosslinked with conventional PEO-silanes such as triethoxysilylpropyl PEO monomethyl ether $\left[(\mathrm{EtO})_{3} \mathrm{Si}-\left(\mathrm{CH}_{2}\right)_{3}-\mathrm{PEO}_{n}-\mathrm{OCH}_{3}\right][24,25]$ and allyl PEO monomethyl ether $\left[\mathrm{CH}_{2}=\mathrm{CHCH}_{2}-\mathrm{PEO}_{n}-\mathrm{OCH}_{3}\right]$ [43] as well as silicones surfacegrafted with allyl PEO monomethyl ether [27, 43]. We recently demonstrated that for silicones bulk-modified with PEO-silanes $(n=3,8$, and 16), poor surface restructuring of PEO was observed [44]. In this way, the surfaces remained hydrophobic, even after exposure to water, and exhibited high protein adsorption similar to that of unmodified silicone. The inability of conventional PEO-silanes to undergo water-driven surface restructuring could explain the poor protein resistance of other bulk-modified polymers [22-24].

We have reported silicones with enhanced protein resistance prepared via bulkmodification with PEO-silane amphiphiles bearing an oligodimethylsiloxane (ODMS) tether [ $\alpha$ $(\mathrm{EtO})_{3}-\left(\mathrm{CH}_{2}\right)_{3}-\mathrm{ODMS}_{m}$-block- $\mathrm{PEO}_{n}-\mathrm{OCH}_{3}$ [ [44-47]. Silicones bulk-modified with these PEOsilane amphiphiles were observed to undergo substantial, rapid, water-driven surface restructuring to form a PEO-enriched surface (by atomic force microscopy [AFM]) [47] with high resistance to proteins [44-47] and other biofoulers [48]. Their ability to function as an effective "surface-modifying additive" (SMA) can be attributed to the ODMS tether's flexibility [40] as well as similar composition and thus compatibility with the silicone matrix. The extent of 
water-driven surface restructuring and protein resistance has been shown to be dependent on ODMS tether length and PEO-segment length. For instance, for PEO-silane amphiphiles of constant PEO-segment length $(m=0,4$, and $13 ; n=8)$, protein resistance of bulk-modified silicones increased with siloxane tether length [45]. More recently, silicones were modified using PEO-silane amphiphiles with a variable PEO-segment length ( $m=13 ; n=3,8$, and 16) (Figure 1) [44]. Water-driven change from a hydrophobic to hydrophilic (i.e. PEO-enriched) surface was evaluated by temporally measuring the static contact angle $\left(\theta_{\text {static }}\right)$ of a deposited water droplet. While initially hydrophobic $\left(\theta_{\text {static, }} 0_{\mathrm{s}} \approx 115^{\circ}\right)$, a rapid and substantial decrease of $\theta_{\text {static }}$ was observed when silicone was modified with $n=8\left(\theta_{\text {static, } 3 \min } \approx 29^{\circ}\right)$ and $n=16\left(\theta_{\text {static, } 3 \min } \approx 57^{\circ}\right)$, but less so with $n=3\left(\theta_{\text {static, } 3 \min } \approx 84^{\circ}\right)$. Thus, the most hydrophilic PEO-modified silicone surface was achieved with $n=8$. In contrast, silicone modified with analogous conventional PEO-silanes ( $n=3,8$, and 16) remained hydrophobic with minimal decrease in $\theta_{\text {static }}$ as a result of their limited surface-restructuring potential.

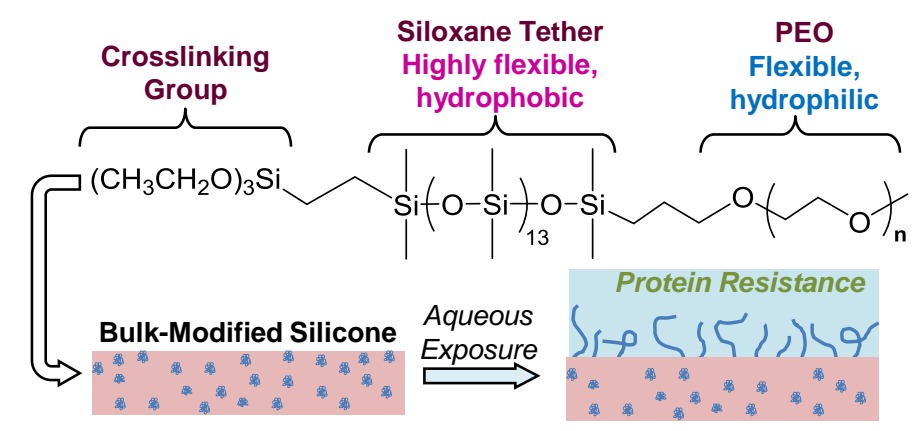

Figure 1. PEO-silane amphiphile chemical structure $(n=3,8$, and 16) and illustration of water-driven surface restructuring of bulk-modified silicone.

In the previous study, PEO-silane amphiphiles $(m=13 ; n=3,8$, and 16) were incorporated into silicone at a single molar concentration of $50 \mu \mathrm{mol}$ (per 1 gram of silicone). 
Due to their different respective molecular weights of the PEO segment (i.e. the $n$ value), at this single molar concentration, the "wt\% of PEO" was variable: $n=3<n=8<n=16$ (Table 1). In this study, the efficacy of these PEO-silane amphiphiles to undergo water-driven restructuring and subsequently reduce protein adsorption was similarly evaluated. However, five concentrations $(5,10,25,50$, and $100 \mu \mathrm{mol}$ per $1 \mathrm{~g}$ silicone) were evaluated to determine the minimum concentration necessary. Furthermore, this series permitted determination as to whether it was PEO length $(n)$ or PEO concentration (irrespective of length) that impacted protein resistance efficacy.

Table 1. Total wt\% of PEO-silane amphiphile (i.e. surface-modifying additive, SMA) and corresponding wt\% of PEO in a modified silicone for each total molar concentration of SMA. [wt\% PEO calculated as the wt\% SMA multiplied by the ratio of PEO $M_{n}(n \times 44$ g/mol) to SMA $\left.M_{n}\right]$

\begin{tabular}{|c|c|c|c|c|c|c|}
\hline \multirow{2}{*}{$\begin{array}{l}\text { Molar Concentration } \\
\text { (per } 1 \mathrm{~g} \text { silicone) }\end{array}$} & \multicolumn{2}{|c|}{$n=3$} & \multicolumn{2}{|c|}{$n=8$} & \multicolumn{2}{|c|}{$n=16$} \\
\hline & wt $\%$ SMA & wt $\%$ PEO & wt $\%$ SMA & wt $\%$ PEO & wt $\%$ SMA & wt $\%$ PEO \\
\hline $5 \mu \mathrm{mol}$ & 0.74 & 0.07 & 0.85 & 0.17 & 1.02 & 0.35 \\
\hline $10 \mu \mathrm{mol}$ & 1.47 & 0.13 & 1.68 & 0.35 & 2.02 & 0.69 \\
\hline $25 \mu \mathrm{mol}$ & 3.59 & 0.32 & 4.10 & 0.84 & 4.90 & 1.67 \\
\hline $50 \mu \mathrm{mol}$ & 6.93 & 0.61 & 7.88 & 1.62 & 9.35 & 3.19 \\
\hline $100 \mu \mathrm{mol}$ & 12.97 & 1.15 & 14.60 & 3.01 & 17.10 & 5.84 \\
\hline
\end{tabular}

\section{Materials and Methods}

\subsection{Materials}

Vinyltriethoxysilane, $\alpha, \omega$-bis-(SiH)oligodimethylsiloxane $\left[\mathrm{M}_{\mathrm{n}}=1000-1100 \mathrm{~g} / \mathrm{mol}\right.$ per manufacturer's specifications; $M_{n}=1096 \mathrm{~g} / \mathrm{mol}$ per ${ }^{1} \mathrm{H}$ NMR end group analysis; ${ }^{1} \mathrm{H}$ NMR $(300$ $\left.\mathrm{MHz}, \mathrm{CDCl}_{3}, \delta\right): 0.05-0.10\left(\mathrm{~m}, 78 \mathrm{H}, \mathrm{SiCH}_{3}\right), 0.185\left(\mathrm{~d}, J=2.7 \mathrm{~Hz}, 12 \mathrm{H}, \mathrm{SiCH}_{3}\right)$, and $4.67-$ $4.73(\mathrm{~m}, 2 \mathrm{H}, \mathrm{SiH})]$, and allyloxy(triethylene oxide) methyl ether $\left[\mathrm{M}_{\mathrm{n}}=204 \mathrm{~g} / \mathrm{mol}\right.$ per 
manufacturer's specifications; $\mathrm{M}_{\mathrm{n}}=204 \mathrm{~g} / \mathrm{mol}$ per ${ }^{1} \mathrm{H}$ NMR end group analysis; ${ }^{1} \mathrm{H}$ NMR $(300$ $\left.\mathrm{MHz}, \mathrm{CDCl}_{3}, \delta\right): 3.35\left(\mathrm{~s}, 3 \mathrm{H}, \mathrm{OCH}_{3}\right), 3.50-3.67\left(\mathrm{~m}, 12 \mathrm{H}, \mathrm{OCH}_{2} \mathrm{CH}_{2}\right), 4.00(\mathrm{dt}, J=6.0$ and 1.5 $\left.\mathrm{Hz}, 2 \mathrm{H}, \mathrm{CH}_{2}=\mathrm{CHCH}_{2} \mathrm{O}\right), 5.13-5.28\left(\mathrm{~m}, 2 \mathrm{H}, \mathrm{CH}_{2}=\mathrm{CHCH}_{2} \mathrm{O}\right)$, and $5.82-5.96(\mathrm{~m}, 1 \mathrm{H}$, $\mathrm{CH}_{2}=\mathrm{CHCH}_{2} \mathrm{O}$ )] were purchased from Gelest. Allyl methyl PEO [Polyglykol AM 450, $\mathrm{M}_{\mathrm{n}}=292$ $-644 \mathrm{~g} / \mathrm{mol}$ per manufacturer's specifications; $\mathrm{M}_{\mathrm{n}}=424 \mathrm{~g} / \mathrm{mol}$ per ${ }^{1} \mathrm{H}$ NMR end group analysis; ${ }^{1} \mathrm{H}$ NMR (300 MHz, $\left.\mathrm{CDCl}_{3}, \delta\right): 3.35$ (s, 3H, OCH$\left.{ }_{3}\right), 3.51-3.66\left(\mathrm{~m}, 32 \mathrm{H}, \mathrm{OCH}_{2} \mathrm{CH}_{2}\right), 4.00(\mathrm{~d}, J$ $\left.=5.4 \mathrm{~Hz}, 2 \mathrm{H}, \mathrm{CH}_{2}=\mathrm{CHCH}_{2} \mathrm{O}\right), 5.13-5.28\left(\mathrm{~m}, 2 \mathrm{H}, \mathrm{CH}_{2}=\mathrm{CHCH}_{2} \mathrm{O}\right)$, and $5.82-5.96(\mathrm{~m}, 1 \mathrm{H}$, $\left.\mathrm{CH}_{2}=\mathrm{CHCH}_{2} \mathrm{O}\right)$ ] was provided by Clariant. Anhydrous magnesium sulfate $\left(\mathrm{MgSO}_{4}\right)$ and glass microscope slides $(75 \mathrm{~mm} \times 25 \mathrm{~mm} \times 1 \mathrm{~mm}$ ) were purchased from Fisher. PEO mono methyl ether $\left[\mathrm{M}_{\mathrm{n}}=750 \mathrm{~g} / \mathrm{mol}\right.$ per manufacturer's specifications, $\mathrm{M}_{\mathrm{n}}=736 \mathrm{~g} / \mathrm{mol}$ per ${ }^{1} \mathrm{H}$ NMR end group analysis; ${ }^{1} \mathrm{H}$ NMR $\left(300 \mathrm{MHz}, \mathrm{CDCl}_{3}, \delta\right): 3.37\left(\mathrm{~s}, 3 \mathrm{H}, \mathrm{OCH}_{3}\right)$ and $3.53-3.73(\mathrm{~m}, 64 \mathrm{H}$, $\left.\mathrm{OCH}_{2} \mathrm{CH}_{2}\right)$ ], sodium hydride $\left(\mathrm{NaH} ; 60 \mathrm{wt} \%\right.$ in mineral oil), allyl bromide, $\operatorname{RhCl}\left(\mathrm{Ph}_{3} \mathrm{P}\right)_{3}$ (Wilkinson's catalyst), and Pt-divinyltetramethyldisiloxane complex (Karstedt's catalyst) were purchased from Sigma-Aldrich and were used as received. Organic solvents were also purchased from Sigma-Aldrich and were dried over $4 \AA$ molecular sieves prior to use. Medical-grade RTV silicone (MED-1137) was purchased from Nusil. Per manufacturer's specifications, MED-1137 is comprised of $\alpha, \omega$-bis( $\mathrm{Si}-\mathrm{OH}) \mathrm{PDMS}$, silica (11-21\%), methyltriacetoxysilane $(<5 \%)$, ethyltriacetoxysilane $(<5 \%)$, and trace amounts of acetic acid. The Alexa Fluor 546-dye conjugate of human fibrinogen (AF-546 HF; $\mathrm{M}_{\mathrm{w}}=340 \mathrm{kDa}$; lyophilized) was obtained from Invitrogen. Phosphate buffered saline (PBS, without calcium and magnesium, $\mathrm{pH}=7.4$ ) was purchased from Cellgro.

\subsection{Synthesis}


PEO-silane amphiphiles $(m=13 ; n=3,8$, and 16) were prepared and characterized as previously reported using a two-step hydrosilylation procedure [44]. Briefly, $\alpha, \omega$-bis$(\mathrm{SiH}) \mathrm{ODMS}_{13}$ was reacted with vinyltriethoxysilane in a regioselective reaction using Wilkinson's catalyst. Next, the product and each allyl methyl PEO ( $n=3,8$, and 16) were reacted with Karstedt's catalyst to afford the corresponding PEO-silane amphiphiles. Allyl methyl PEO ( $n=16)$ was synthesized using established methods [44].

\subsection{Film Preparation}

Glass microscope slides were sequentially rinsed with dichloromethane (DCM) and acetone followed by drying in a $120^{\circ} \mathrm{C}$ oven overnight. Silicone films were prepared by solventcasting onto glass microscope slides. Each casting solution consisted of $2.0 \mathrm{~g}$ of uncured MED1137 dissolved in $9 \mathrm{~mL}$ hexane (25 wt\%). Each PEO-silane amphiphile was thoroughly mixed into the casting solution with a vortexer at the following molar concentrations: $5,10,25,50$, and $100 \mu \mathrm{mol}$ (per $1 \mathrm{~g} \mathrm{MED-1137).} \mathrm{Solutions} \mathrm{were} \mathrm{solvent-cast} \mathrm{onto} \mathrm{leveled} \mathrm{glass} \mathrm{microscope} \mathrm{slides}$ (1.5 mL per slide) and a polystyrene Petri dish cover placed on top to reduce the rate of solvent evaporation and prevent bubble formation. Films were allowed to cure one week at room temperature (RT) before analysis. Unmodified silicone films (i.e. containing no PEO-silane amphiphile) were likewise prepared as controls.

\subsection{Water Contact Angle Analysis}

Static contact angles $\left(\theta_{\text {static }}\right)$ of distilled/DI water droplets on silicone films were measured at RT using a CAM-200 goniometer (KSV Instruments) equipped with an autodispenser, video camera, and drop-shape analysis software (Attension Theta). Following 
deposition of a $5 \mu \mathrm{L}$ sessile drop of water, the contact angle was measured every 15 seconds over a 5 min period. The reported values at each time point are the averages and standard deviations of three measurements on different regions of the same film.

\subsection{Protein Adsorption}

AF-546 HF adsorption onto films was measured via fluorescence microscopy. On each film, a silicone isolator well (20 mm well diameter, $2 \mathrm{~mm}$ depth; McMaster-Carr) was pressed against the surface, thereby creating a seal which prevented leakage of solution from the well. HF solution (100 $\mu \mathrm{g} \mathrm{mL}^{-1}$ in PBS, $\left.0.7 \mathrm{~mL}\right)$ was added to each well. (Note: Per manufacturer's specifications, the AF-546 HF was first dissolved in $0.1 \mathrm{M} \mathrm{NaHCO}_{3}$ to obtain a $1.5 \mathrm{mg} \mathrm{mL}^{-1}$ solution that was further diluted in PBS to obtain the final concentration of $100 \mu \mathrm{g} \mathrm{mL}^{-1}$.) After 3 $\mathrm{h}$ at RT and protected from light, the solution was removed and $0.7 \mathrm{~mL}$ of fresh PBS was added to each well and then removed after 5 min. This process was repeated five times with fresh PBS and lastly once with DI water. The protein-exposed films were dried under a stream of air and protected from light until imaged. For each film composition, an additional film was prepared and likewise rinsed with PBS and DI water, but without exposure to HF solution (i.e. soaked $3 \mathrm{~h}$ in PBS) in order to correct for the background intensity.

A FV1000 (Olympus) laser scanning confocal microscope was used for quantification of HF adsorption on all silicone films. Imaging conditions (both in excitation and collection) were identical for all samples: objective (SPLSAPO 10x objective, NA 0.40), laser excitation type and intensity (HeNe $543 \mathrm{~nm}$ source), field of view and resolution (256 x 256 pixels, $317 \times 317 \mu \mathrm{m}$ field of view), depth (40 slices at $1 \mu \mathrm{m}$ per slice), slice averaging, and collection (150 $\mu \mathrm{m}$ pinhole, $560 \mathrm{~nm}$ long-pass filter followed by a $560-660 \mathrm{~nm}$ band-pass filter, identical photo- 
multiplier voltages/sensitivities). Data analysis was performed on the FV10-ASW v3.1 software suite (Olympus). Each HF-exposed film was imaged in three randomly-selected locations within the region of HF solution exposure and aggregate intensities computed. These were compared to three images obtained from the analogous surface that had similar treatment without HF exposure. Changes in intensity from exposure to HF were then obtained and compared, with errors reported as the standard deviation of the three measurements.

\subsection{Statistical Analysis}

Contact angle and fibrinogen adsorption data are reported as the mean \pm standard deviation. For fibrinogen adsorption data, mean values were compared using ANOVA followed by a Tukey post hoc test with a $p$-value $<0.07$ considered statistically different.

\section{Results and Discussion}

\subsection{Surface Restructuring}

The efficacy of PEO-silane amphiphiles ( $n=3,8$, and 16) as SMAs to produce proteinresistant silicones was evaluated first in terms of their capacity to undergo water-driven surface reorganization to form a hydrophilic, PEO-enriched surface. The water-driven restructuring of PEO to the surface of such bulk-modified silicones has been directly observed [47]. In addition, temporally measuring the $\theta_{\text {static }}$ of a deposited water droplet has been shown to effectively monitor reorganization of PEO to the surface-water interface [44-46]. Therefore, the 15 bulkmodified silicones and unmodified silicone control $(0.14 \pm 0.01 \mathrm{~mm}$ thick by electronic caliper $)$ were evaluated by measuring $\theta_{\text {static }}$ of water droplets over a 5 min period. In this way, the rate of migration of PEO to the surface-water interface was characterized by how quickly $\theta_{\text {static }}$ 
decreased (i.e. the rate of increase in surface hydrophilicity). The final value of $\theta_{\text {static }}$ (i.e. at 5 min) reflected the hydrophilicity achieved through PEO migration. Therefore, lower $\theta_{\text {static }}$ values were indicative of higher PEO surface coverage which was expected to better resist protein adsorption.

For each PEO-silane amphiphile, the molar concentration had a distinct impact on the rate and extent of water-driven surface restructuring of bulk-modified silicones and the final hydrophilicity achieved (Figure 2, Tables S1-S3). For all concentrations, the bulk-modified silicones are initially similarly hydrophobic when compared to the unmodified silicone (i.e. high $\left.\theta_{\text {static, } 0 \mathrm{~s}}\right)$, reflecting a lack of PEO at the surface. At the lowest concentration $(5 \mu \mathrm{mol})$, minimal restructuring was observed and the modified silicone surfaces remained quite hydrophobic, even at the 5 min time point. At higher concentrations, restructuring behavior varied with the PEOsegment length $(n)$. For $n=3$, increasing the concentration from 10 to $100 \mu$ mol produced a somewhat small change in the achieved hydrophilicity (i.e. $\theta_{\text {static, } 5 \min }=93$ and $76^{\circ}$, respectively). Moreover, at each concentration, the majority of the water-driven restructuring occurred by $15 \mathrm{~s}$. Despite rapid reorganization, the low number of PEO repeat units limited its capacity to increase surface hydrophilicity, even at high concentrations. In stark contrast, $n=8$ restructured at a rapid rate to form hydrophilic surfaces, even at a low concentration of $10 \mu \mathrm{mol}\left(\theta_{\mathrm{static}, 5 \mathrm{~min}}=72^{\circ}\right)$. At higher concentrations, surfaces ultimately became exceptionally hydrophilic as characterized by

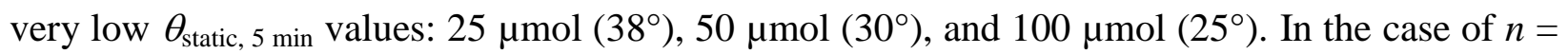
16, substantial restructuring, resulting in a notable increase in surface hydrophilicity, did not occur until the concentration was $25 \mu \mathrm{mol}$ or higher. At these concentrations, $\theta_{\text {static, } 5 \text { min values }}$ were higher for $n=16$ versus for $n=8$, but were lower than for $n=3$. Also, the total wt $\%$ of PEO-silane amphiphile corresponding to the minimum effective molar concentration is much 
less for $n=8(10 \mu \mathrm{mol} ; 1.68 \mathrm{wt} \%)$ versus $n=16(25 \mu \mathrm{mol} ; 4.90 \mathrm{wt} \%)$ (Table 1). Thus, on the basis of molar concentration and total wt\% incorporated into silicone, the PEO-silane amphiphile with the intermediate length $(n=8)$ was the most efficient SMA.
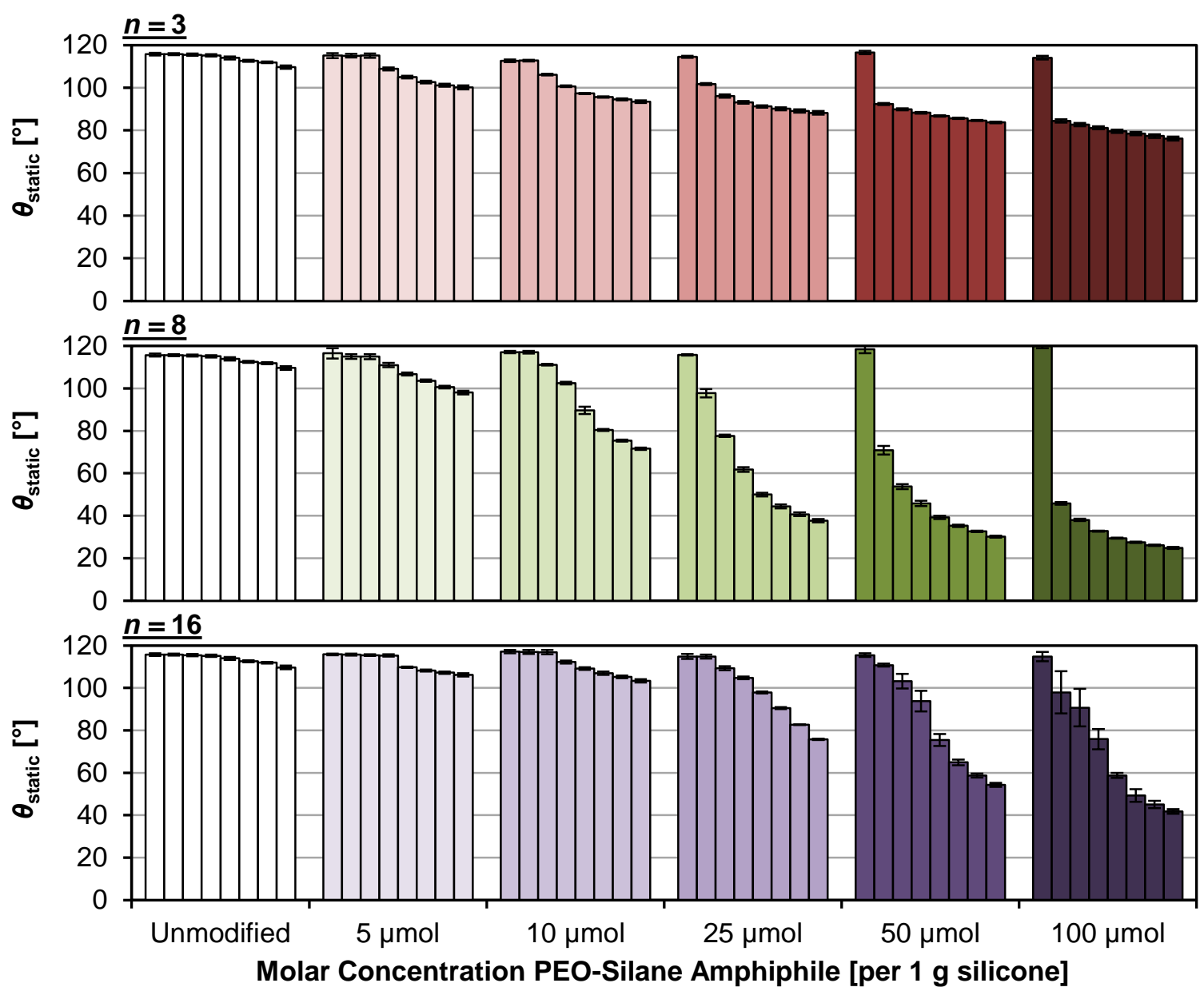

Figure 2. Static water contact angle $\left(\theta_{\text {static }}\right)$ measured over a 5 min period on bulk-modified silicone films. For each sample, bars are organized as the time after initial drop placement from left to right as follows: $0 \mathrm{~s}, 15 \mathrm{~s}, 30 \mathrm{~s}, 1 \mathrm{~min}, 2 \mathrm{~min}, 3 \mathrm{~min}, 4 \mathrm{~min}$, and $5 \mathrm{~min}$. Each bar represents the average of measurements made on three water droplets on the same sample at the same time point and the error bar is the standard deviation.

In addition to the "total molar concentration," the efficacy of PEO-silane amphiphiles as SMAs was also considered in terms of the "PEO concentration" expressed in terms of "wt\% PEO" (Table 1). This permits validation that it is the PEO length that gives rise to differences in water-driven surface restructuring (Figure 2) rather than PEO concentration independent of 
length. Because of the different molecular weights of the PEO segments $(n=3,8$, and 16$)$, for a given molar concentration, the contribution from PEO increases with segment length. For instance, at $10 \mu \mathrm{mol}$ PEO-silane amphiphile, the wt\% PEO increases in the order: $0.13(n=3)<$ $0.35(n=8)<0.69(n=16)$. To determine the impact of PEO length versus PEO concentration (i.e. wt\% PEO), one series of modified silicones is particularly illustrative. Silicones prepared with $n=3(25 \mu \mathrm{mol}), n=8(10 \mu \mathrm{mol})$, and $n=16(5 \mu \mathrm{mol})$ contain the same PEO concentration $(0.32-0.35 \mathrm{wt} \%)$. However, their surface-restructuring profiles are quite different and $\theta_{\text {static, } 5 \text { min }}$ $=88^{\circ}, 72^{\circ}$, and $106^{\circ}$, respectively. Thus, this confirms that PEO length $(n)$ dictates surface restructuring and hydrophilicity, rather than simply concentration independent of length.

Having confirmed the significance of PEO length for surface reorganization, the observed results can be explained on the basis of PEO-silane amphiphile steric effects as well as solubility in the silicone matrix. For longer PEO segments, steric hindrance may reduce surface restructuring potential. Also, in prior work [44], the transparency of modified silicones was observed to decrease with PEO length: $n=3>n=8>n=16$. Thus, longer PEO segments were more prone to phase separation which would be expected to reduce their affinity for water and thus their tendency to migrate to the surface-water interface. Given the low molecular weight of $n=3$, the rapid restructuring can be attributed to its low steric hindrance and greater solubility in silicone. However, the low number of PEO repeat units reduces its ability to give rise to substantial hydrophilicity. For $n=16$, its restructuring is relatively inhibited by the chain length as well as phase separation within the silicone, requiring higher concentrations $(\geq 25 \mu \mathrm{mol})$ to achieve substantial water-driven hydrophilicity. Thus, $n=8$ represents the most efficient PEO length, striking a balance between these two effects to achieve hydrophilicity at the surface-water interface at only $10 \mu \mathrm{mol}$. 


\subsection{Protein Resistance}

Adsorbed fibrinogen plays a well-established role in the initiation of surface-induced thrombosis $[49,50]$ and is commonly used to evaluate material thrombogenicity in vitro $[14,27$, 34, 46, 47, 51]. Oeveren et al. concluded that fibrinogen adsorption was one of the most reliable methods to predict thrombogenicity for many materials [52]. Furthermore, silicone was found to adsorb the most fibrinogen of all the materials tested, which could explain silicone's high susceptibility to thrombosis. Therefore, fibrinogen adsorption was utilized in this study to evaluate the thromboresistance of bulk-modified silicone films.

Resistance of bulk-modified silicone films to HF adsorption was determined using confocal microscopy [44]. Following exposure to a solution of fluorescently labeled HF (100 $\mu \mathrm{g}$

$\mathrm{mL}^{-1} ; 3 \mathrm{~h}$ ), the resulting fluorescence intensity of each film was measured (Table S4) and normalized to that of the unmodified silicone (Figure 3). As expected, HF adsorption was relatively high for the unmodified silicone. The efficacy of the PEO-silane amphiphiles $(n=3,8$, and 16) to reduce protein adsorption onto surfaces was impacted by PEO-segment length as well as molar concentration, with protein resistance corresponding to their ability to undergo waterdriven restructuring to achieve hydrophilicity (per Figure 2). At all molar concentrations, silicone modified with $n=3$ adsorbed high levels of HF similar to unmodified silicone. This agrees with the observed lack of hydrophilicity, even at higher concentrations. Modification of silicone with $n=8$ dramatically reduced HF adsorption at molar concentrations as low as 10 $\mu$ mol. As the concentration was increased, protein adsorption levels remained very low but did not substantially change. Thus, while increasing the molar concentration beyond $10 \mu \mathrm{mol}$ led to surfaces with greater water-induced hydrophilicity, it did not additionally benefit protein 
resistance. This indicates that the surface presents a sufficient amount of PEO $(n=8)$ at $10 \mu$ mol. In the case of $n=16$, the minimum molar concentration required was $25 \mu \mathrm{mol}$, with higher concentrations not leading to an improvement in protein resistance. Again, this parallels the observation that a $25 \mu \mathrm{mol}$ concentration is required to achieve water-induced hydrophilicity. Although hydrophilicity increases somewhat at higher concentrations (50 and $100 \mu \mathrm{mol}$ ), it is not necessary for high protein resistance.

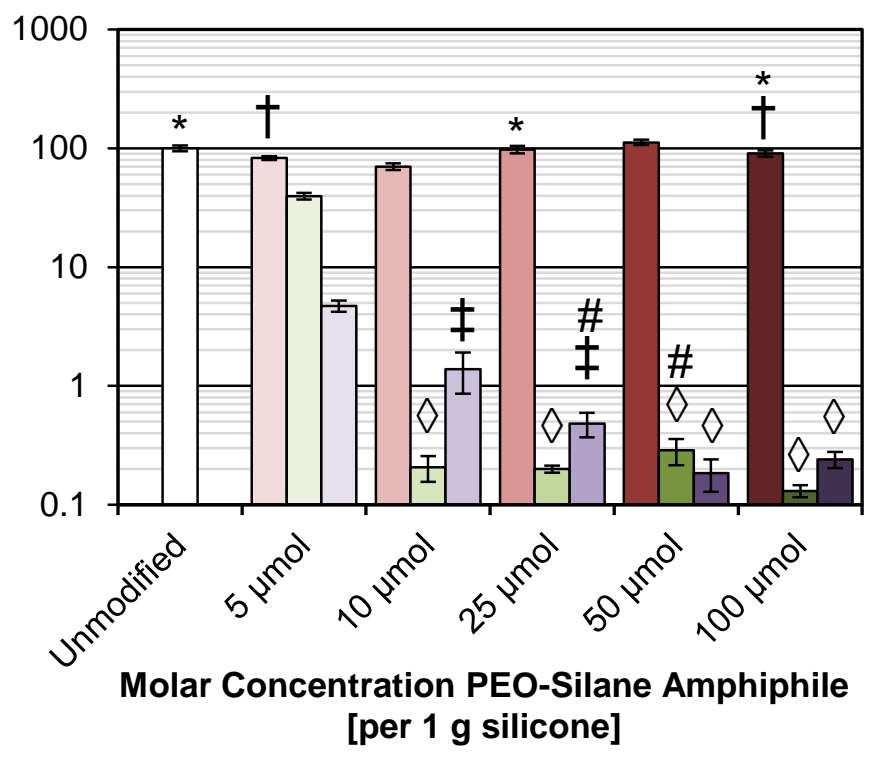

Figure 3. HF adsorption on bulk-modified silicone films as measured by fluorescence intensity with confocal microscopy. Each bar represents the average and standard deviation of pixel intensity for three images of the sample normalized to that of unmodified silicone. Each set of three bars indicates sample fluorescence at the given concentration for $n=3$ (left), $n=8$ (middle), and $n=16$ (right). Shared symbols indicate data sets that are not statistically distinct $(p>0.07)$. 
To achieve protein resistance and subsequent thromboresistance, a SMA is required that can be incorporated into silicones so as to effectively induce water-driven PEO-enrichment and hydrophilicity at the surface. PEO-silane amphiphiles comprised of a siloxane tether $(m)$ and a PEO segment $(n)$ represent a new class of SMAs with the potential to do so. When evaluated previously at a constant molar concentration (50 $\mu$ mol per $1 \mathrm{~g}$ silicone), PEO-silane amphiphiles ( $m=13$ ) dramatically improved protein resistance of silicones when $n=8$ and 16 but not when $n$ $=3$. In this work, the efficacy of these PEO-silane amphiphiles $(m=13 ; n=3,8$, and 16) was explored in terms of the minimum molar concentration required as well as the significance of the PEO-segment length. Each PEO-silane amphiphile was incorporated into a silicone at 5, 10, 25, 50, and $100 \mu \mathrm{mol}$ (per $1 \mathrm{~g}$ silicone). Even at higher concentrations, while $n=3$ produced rapid, water-driven restructuring of modified silicones, it did not achieve appreciable hydrophilicity nor protein resistance. In contrast, at a concentration of only $10 \mu \mathrm{mol}, n=8$ achieved high protein resistance. This represents a total concentration of $n=8$ of only $1.68 \mathrm{wt} \%$. While increasing the molar concentration further enhanced water-induced hydrophilicity, it did not lead to further substantial reductions in protein adsorption. Finally, for $n=16$, the minimum concentration required for protein resistance was found to be higher $(25 \mu \mathrm{mol} ; 4.90 \mathrm{wt} \%)$. When compared on the basis of "wt\% PEO", it was determined that PEO length did in fact influence surface restructuring and protein resistance, with $n=8$ being the most effective. The efficacy of $n=8$ to undergo water-driven surface migration and induce subsequent protein resistance may be attributed to the balance of steric effects and solubility in the silicone matrix. Given the low concentration $(10 \mu \mathrm{mol} ; 1.68 \mathrm{wt} \%)$ necessary to invoke a substantial reduction in protein adsorption, the $n=8 \mathrm{PEO}$-silane amphiphile is considered to be a potent SMA for silicones.

\section{Acknowledgements}


The authors thank the Texas Engineering and Experiment Station (TEES) for financial support of this research. M. A. Rufin gratefully acknowledges support from the NIH (3R01DK95101-02S1). J. E. Raymond acknowledges support from the Office of Naval Research (N00014-14-1-0082) and the Welch Foundation (\#A-0001).

\section{References}

[1] Van Dyke ME, Clarson SJ, Arshady R. Silicone Biomaterials. In: Arshady R, editor. An Introduction to Polymeric Biomaterials. London: Citrus Books; 2003. p. 109-35.

[2] Curtis J, Colas A. Medical Applications of Silicones. In: Ratner BD, Hoffman AS, Schoen FJ, Lemons JE, editors. Biomaterials Science: An Introduction to Materials in Medicine. 2nd ed. New York: Elsevier Academic Press; 2004. p. 697-707.

[3] Brash JL. Hydrophobic polymer surfaces and their interactions with blood. Ann NY Acad Sci 1977;283:356-71.

[4] Whitman ED. Complications associated with the use of central venous access devices. Curr Prob Surg 1996;33:309-78.

[5] Park SJ, Milano CA, Tatooles AJ, Rogers JG, Adamson RM, Steidley DE, et al. Outcomes in advanced heart failure patients with left ventricular assist devices for destination therapy. Circ Heart Fail 2012;5:241-8.

[6] Räber L, Magro M, Stefanini GG, Kalesan B, van Domburg RT, Onuma Y, et al. Very late coronary stent thrombosis of a newer-generation everolimus-eluting stent compared with early-generation drug-eluting stents: A prospective cohort study. Circulation 2012;125:1110-21.

[7] Fux CA, Uehlinger D, Bodmer T, Droz S, Zellweger C, Mühlemann K. Dynamics of hemodialysis catheter colonization by coagulase-negative staphylococci. Infect Cont Hosp Ep 2005;26:567-74.

[8] Kumar V, Rauscher H, Brétagnol F, Arefi-Khonsari F, Pulpytel J, Colpo P, et al. Preventing Biofilm Formation on Biomedical Surfaces. In: Rauscher H, Perucca M, Buyle G, editors. Plasma Technology for Hyperfunctional Surfaces: Food, Biomedical, and Textile Applications. Weinheim: Wiley-VCH Verlag GmbH \& Co. KGaA; 2010. p. 183-223.

[9] Colì L, Donati G, Cianciolo G, Raimondi C, Comai G, Panicali L, et al. Anticoagulation therapy for the prevention of hemodialysis tunneled cuffed catheters (TCC) thrombosis. J Vasc Access 2006;7:118-22.

[10] Willms L, Vercaigne LM. Does warfarin safely prevent clotting of hemodialysis catheters? Semin Dial 2008;21:71-7.

[11] Guerrouij M, Uppal C, Alklabi A, Douketis J. The clinical impact of bleeding during oral anticoagulant therapy. J Thromb Thrombolys 2011;31:419-23.

[12] Stulak JM, Lee D, Haft JW, Romano MA, Cowger JA, Park SJ, et al. Gastrointestinal bleeding and subsequent risk of thromboembolic events during support with a left ventricular assist device. J Heart Lung Transpl 2014;33:604. 
[13] Pale-Grosdemange C, Simon ES, Prime KL, Whitesides GM. Formation of self-assembled monolayers by chemisorption of derivatives of oligo(ethylene glycol) of structure $\mathrm{HS}\left(\mathrm{CH}_{2}\right)_{11}\left(\mathrm{OCH}_{2} \mathrm{CH}_{2}\right)_{\mathrm{m}} \mathrm{OH}$ on gold. J Am Chem Soc 1991;113:12-20.

[14] Prime KL, Whitesides GM. Adsorption of proteins onto surfaces containing end-attached oligo(ethylene oxide): a model system using self-assembled monolayers. J Am Chem Soc 1993;115:10714-21.

[15] Sofia SJ, Premnath V, Merrill EW. Poly(ethylene oxide) grafted to silicon surfaces: grafting density and protein adsorption. Macromolecules 1998;31:5059-70.

[16] Zhang M, Desai T, Ferrari M. Proteins and cells on PEG immobilized silicon surfaces. Biomaterials 1998;19:953-60.

[17] Papra A, Gadegaard N, Larsen NB. Characterization of ultrathin poly(ethylene glycol) monolayers on silicon substrates. Langmuir 2001;17:1457-60.

[18] Gombotz WR, Guanghui W, Hoffman AS. Immobilization of poly(ethylene oxide) on poly(ethylene terephthalate) using a plasma polymerization process. J Appl Polym Sci 1989;37:91-107.

[19] Desai NP, Hubbell JA. Biological responses to polyethylene oxide modified polyethylene terephthalate surfaces. J Biomed Mater Res 1991;25:829-43.

[20] Bergström K, Holmberg K, Safranj A, Hoffman AS, Edgell MJ, Kozlowski A, et al. Reduction of fibrinogen adsorption on PEG-coated polystyrene surfaces. J Biomed Mater Res 1992;26:779-90.

[21] Lee JH, Ju YM, Kim DM. Platelet adhesion onto segmented polyurethane film surfaces modified by addition and crosslinking of PEO-containing block copolymers. Biomaterials 2000;21:683-91.

[22] Okkema AZ, Grasel TG, Zdrahala RJ, Solomon DD, Cooper SL. Bulk, surface, and blood-contacting properties of polyetherurethanes modified with polyethylene oxide. J Biomat Sci Polym E 1989;1:43-62.

[23] Chaikof EL, Merrill EW, Callow AD, Connolly RJ, Verdon SL, Ramberg K. PEO enhancement of platelet deposition, fibrinogen deposition, and complement C3 activation. J Biomed Mater Res 1992;26:1163-8.

[24] Chen H, Brook MA, Chen Y, Sheardown H. Surface properties of PEO-silicone composites: reducing protein adsorption. J Biomat Sci Polym E 2005;16:531-48.

[25] Chen H, Brook MA, Sheardown H. Silicone elastomers for reduced protein adsorption. Biomaterials 2004;25:2273-82.

[26] Lee S, Vörös J. An aqueous-based surface modification of poly(dimethylsiloxane) with poly(ethylene glycol) to prevent biofouling. Langmuir 2005;21:11957-62.

[27] Chen H, Zhang Z, Chen Y, Brook MA, Sheardown H. Protein repellant silicone surfaces by covalent immobilization of poly(ethylene oxide). Biomaterials 2005;26:2391-9.

[28] Jeon SI, Andrade JD. Protein-surface interactions in the presence of polyethylene oxide: II. Effect of protein size. J Colloid Interface Sci 1991;142:159-66.

[29] Jeon SI, Lee JH, Andrade JD, De Gennes PG. Protein-surface interactions in the presence of polyethylene oxide: I. Simplified theory. J Colloid Interface Sci 1991;142:149-58.

[30] Szleifer I. Protein adsorption on surfaces with grafted polymers: A theoretical approach. Biophys J 1997;72:595-612. 
[31] Chen S, Li L, Zhao C, Zheng J. Surface hydration: Principles and applications toward low-fouling/nonfouling biomaterials. Polymer 2010;51:5283-93.

[32] Harris JM. Poly(Ethylene Glycol) Chemistry: Biotechnical and Biomedical Applications. New York: Plenum Press; 1992.

[33] Browning MB, Cereceres SN, Luong PT, Cosgriff-Hernandez EM. Determination of the in vivo degradation mechanism of PEGDA hydrogels. J Biomed Mater Res A 2014;102:4244-51.

[34] Park K, Shim Hong S, Dewanjee Mrinal K, Eigler Neal L. In vitro and in vivo studies of PEO-grafted bloodcontacting cardiovascular prostheses. J Biomat Sci Polym Ed 2000;11:1121-34.

[35] Du YJ, Klement P, Berry LR, Tressel P, Chan AKC. In vivo rabbit acute model tests of polyurethane catheters coated with a novel antithrombin-heparin covalent complex. Thromb Haemostasis 2005;94:366-72.

[36] Hunt JA, Meijs G, Williams DF. Hydrophilicity of polymers and soft tissue responses: A quantitative analysis. J Biomed Mater Res 1997;36:542-9.

[37] Malmsten M, Emoto K, Van Alstine JM. Effect of chain density on inhibition of protein adsorption by poly(ethylene glycol) based coatings. J Colloid Interface Sci 1998;202:507-17.

[38] Kingshott P, Thissen H, Griesser HJ. Effects of cloud-point grafting, chain length, and density of PEG layers on competitive adsorption of ocular proteins. Biomaterials 2002;23:2043-56.

[39] Owen MJ. Surface Chemistry and Applications. In: Clarson SJ, Semlyen JA, editors. Siloxane Polymers. Englewood Cliffs: Prentice Hall; 1993. p. 309.

[40] Lane TH, Burns SA. Silica, Silicon and Silicones... Unraveling the Mystery. In: Potter M, Rose NR, editors. Immunology of Silicones. Berlin: Springer; 1996. p. 3-12.

[41] Yasuda H, Sharma AK, Yasuda T. Effect of orientation and mobility of polymer molecules at surfaces on contact angle and its hysteresis. J Polym Sci Pol Phys 1981;19:1285-91.

[42] Owen MJ, Smith PJ. Plasma treatment of polydimethylsiloxane. J Adhes Sci Technol 1994;8:1063-75.

[43] Thompson DB, Fawcett AS, Brook MA. Simple Strategies to Manipulate Hydrophilic Domains in Silicones. In: Ganachaud F, Boileau S, Boury B, editors. Silicon Based Polymers: Springer; 2008. p. 29-38.

[44] Rufin MA, Gruetzner JA, Hurley MJ, Hawkins ML, Raymond ES, Raymond JE, et al. Enhancing the protein resistance of silicone via surface-restructuring PEO-silane amphiphiles with variable PEO length. J Mater Chem B 2015;3:2816-25.

[45] Murthy R, Cox CD, Hahn MS, Grunlan MA. Protein-resistant silicones: Incorporation of poly(ethylene oxide) via siloxane tethers. Biomacromolecules 2007;8:3244-52.

[46] Hawkins ML, Grunlan MA. The protein resistance of silicones prepared with a PEO-silane amphiphile. J Mater Chem 2012;22:19540-6.

[47] Hawkins ML, Rufin MA, Raymond JE, Grunlan MA. Direct observation of the nanocomplex surface reorganization of antifouling silicones containing a highly mobile PEO-silane amphiphile. J Mater Chem B 2014;2:5689-97.

[48] Hawkins ML, Faÿ F, Réhel K, Linossier I, Grunlan MA. Bacteria and diatom resistance of silicones modified with PEO-silane amphiphiles. Biofouling 2014;30:247-58. 
[49] Wu Y, Simonovsky FI, Ratner BD, Horbett TA. The role of adsorbed fibrinogen in platelet adhesion to polyurethane surfaces: A comparison of surface hydrophobicity, protein adsorption, monoclonal antibody binding, and platelet adhesion. J Biomed Mater Res A 2005;74A:722-38.

[50] Tsai W-B, Grunkemeier JM, Horbett TA. Human plasma fibrinogen adsorption and platelet adhesion to polystyrene. J Biomed Mater Res 1999;44:130-9.

[51] Murthy R, Bailey BM, Valentin-Rodriguez C, Ivanisevic A, Grunlan MA. Amphiphilic silicones prepared from branched PEO-silanes with siloxane tethers. J Polym Sci Pol Chem 2010;48:4108-19.

[52] van Oeveren W, Haan J, Lagerman P, Schoen P. Comparison of coagulation activity tests in vitro for selected biomaterials. Artif Organs 2002;26:506-11. 
PEO-Silane Amphiphile PEO-Silane Amphiphile $\left(\mathrm{CH}_{3} \mathrm{CH}_{2} \mathrm{O}\right)_{3} \mathrm{Si}$ SifO-Si-O-Si Bulk-Modified Water-Driven PEO Surface Restructuring

\begin{tabular}{|c|c|c|}
\hline \multicolumn{3}{|c|}{ Water-Driven PEO Surface Restructuring } \\
\hline $\mathrm{n}=\mathbf{3}$ & $n=8$ & $n=16$ \\
\hline $\begin{array}{c}\text { prapid restructuring } \\
\text { poor protein resistance }\end{array}$ & 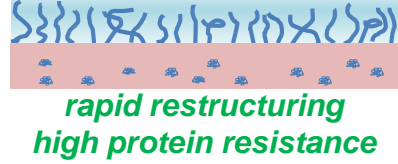 & $\begin{array}{l}\text { S2S } \\
\text { reduced restructuring } \\
\text { high protein resistance }\end{array}$ \\
\hline
\end{tabular}

